\title{
Hasil Belajar Muatan Bahasa Indonesia Tema Lingkungan Sahabat Menggunakan Media Spinning Wheel Kelas V SDN 007 Samarinda Ulu
}

\author{
Hani Subakti ${ }^{\bowtie}$ \\ ${ }^{1}$ Universitas Widya Gama Mahakam Samarinda \\ ${ }^{1}$ hanisubakti@uwgm.ac.id.
}

Abstract: Student learning outcome is still less satisfying especially for Bahasa subject in the elementary school these days. Thus, it becomes the basis of this research which aims to measure the students' achievement of Bahasa content on the theme of friendly environment using spinning wheel media for class $V$ students at SDN 001 Samarinda Ulu. The subjects were 30 students at the fifth grade. This research has been carried out in two cycles. The implementation phase of each cycle consists of planning, acting, observing, and reflecting. The final results of the study showed that there was an improvement in students learning outcomes. In the first cycle, the average test score was 69.5 with a percentage of completeness $60 \%$ and the percentage of incomplete is $40 \%$. While in cycle II, the average test score has increased to 81.3 with a percentage of completeness of $86.7 \%$ and percentage of incomplete $13.3 \%$. Based on this findings, it can be concluded that the spinning wheel media can improve student learning outcomes of Bahasa content on the theme of the friendly environment for fifth grade students at SDN 007 Samarinda Ulu in the 2019/2020 study year.

Keywords: learning outcomes, Indonesian content, spinning wheel.

\begin{abstract}
Abstrak: Hasil belajar siswa masih kurang memuaskan khususnya pada muatan bahasa Indonesia di sekolah dasar. Hal ini menjadi dasar bagi penelitian ini yang memiliki tujuan untuk mengukur hasil belajar muatan bahasa Indonesia pada tema lingkungan sahabat menggunakan media spinning wheel kelas V SDN 001 Samarinda Ulu. Subjek penelitian adalah siswa kelas V yang berjumlah 30 siswa. Penelitian ini telah dilaksanakan sebanyak dua siklus. Tahap pelaksanaan setiap siklus terdiri dari perencanaan, pelaksanaan, pengamatan, dan refleksi. Teknik pengumpulan data menggunakan observasi, tes, wawancara, dan dokumentasi. Adapun hasil akhir dari penelitian menunjukan bahwa terjadi peningkatan hasil belajar. Pada siklus I hasil belajar siswa dengan nilai tes rata-rata 69,5 dengan presentase ketuntasan $60 \%$ dan presentase tidak tuntas yaitu $40 \%$. Sedangkan pada siklus II hasil belajar siswa dengan nilai tes rata-rata 81,3 meningkat dengan presentase ketuntasan $86,7 \%$ dan presentase tidak tuntas 13,3\%. Berdasarkan hasil penelitian tersebut, maka dapat disimpulkan bahwa media spinning wheel dapat meningkatkan hasil belajar muatan bahasa Indonesia tema lingkungan sahabat siswa kelas V SDN 007 Samarinda Ulu tahun pembelajaran 2019/2020.
\end{abstract}

Kata kunci: hasil belajar, muatan bahasa Indonesia, spinning wheel

Sitasi Artikel:

Subakti, H. (2020). Hasil Belajar Muatan Bahasa Indonesia Tema Lingkungan Sahabat Menggunakan Media Spinning Wheel Kelas V SDN 007 Samarinda Ulu. Disastra: Jurnal Pendidikan Bahasa dan Sastra Indonesia, 2(2), 192-206. doi:http://dx.doi.org/10.29300/disastra.v2i2.3067 


\section{Pendahuluan}

Masyarakat di Indonesia sangat memperhatikan pendidikan untuk generasi penerus bangsa agar berguna bagi keluarga, masyarakat, bangsa, dan negara. Memperoleh pendidikan adalah salah satu hak yang harus didapatkan oleh anak bangsa dan sebagai sumber daya manusia untuk memajukan bangsa. Pendidikan di sekolah dasar merupakan upaya untuk mencerdaskan dan mencetak kehidupan bangsa yang bertakwa, bangga terhadap bangsa dan negara, memiliki keterampilan, berjiwa kreatif, dan memiliki budi pekerti yang santun serta mampu menyelesaikan masalah di lingkungan tempat tinggalnya. Sistem pendidikan nasional yang diatur dalam Undang-undang No. 20 Tahun 2003 menjelaskan bahwa pengertian pendidikan adalah usaha sadar dan terencana yang tertuang ke dalam tujuan pendidikan nasional dan pendidikan di sekolah dasar yaitu, untuk mewujudkan suasana belajar dan proses kegiatan pembelajaran dengan tujuan mengembangkan potensi diri secara aktif untuk memiliki kekuatan spiritual keagamaan, pengendalian diri, kepribadian, kecerdasan, akhlak mulia, serta memiliki keterampilan yang diperlukan dalam dirinya dan dalam lingkungan masyarakat, bangsa, dan negara.

Pendidikan di tingkat dasar dikembangkan sesuai dengan satuan pendidikan, potensi daerah atau karakteristik daerah, dan sosial budaya masyarakat. Anak yang telah berusia antara 7 tahun sampai dengan 13 tahun dan telah tercatat sebagai siswa sekolah dasar dapat ditempa berbagai bidang studi yang mengharuskan mereka menguasai kesemua bidang tersebut. Belajar yang perlu ditekankan adalah melalui pengalaman langsung yang termuat dalam kurikulum 2013 dalam pembelajaran tematik terpadu, di mana semua pembelajarannya terintegrasi dan mengharuskan siswa untuk lebih aktif. Proses pembelajaran yang termuat dalam kurikulum 2013 terdapat kegiatan yang meliputi mengamati, menanya, mengeksplorasi, mengolah informasi, dan mengomunikasikannya.

Peningkatan kualitas pendidikan dipengaruhi oleh beberapa komponen pendidikan yaitu tenaga pengajar atau guru, siswa, metode pembelajaran, strategi pembelajaran, dan media pembelajaran. Proses pembelajaran guru mempunyai peran penting untuk meningkat mutu pendidikan melalui pengajaran yang diberikan, yaitu salah satunya melalui media pembelajaran. Peran media dalam pembelajaran merupakan alat fisik yang menimpan pesan dan dapat merangsang siswa dalam pembelajaran serta digunakan untuk proses belajar mengajar. Oleh karena itu peran media sangat membantu guru mempermudah menyampaikan materi kepada siswa.

Pemilihan media yang menarik digunakan adalah dalam bentuk permainan. Media sangat membantu dalam pembelajaran dan bisa menjadi tolok ukur dalam berhasilnya suatu pembelajaran yang mudah dipahami dan menarik untuk peserta didik. Salah satu contoh media yang dapat digunakan dalam pembelajaran adalah media spinning wheel atau roda putar. Media pembelajaran spinning wheel atau roda putar adalah salah satu alat berupa yang berputar berbentuk lingkaran yang terdapat bermacam gambar di dalamnya serta bergerak sesuai porosnya dan berhenti disalah satu bagian gambar. Oleh karena itu peneliti ingin menggunakan media 
pembelajaran spinning wheel dalam pembelajaran untuk mempermudah tingkat kepahaman peserta didik dan membuat pembelajaran menjadi menarik.

Media pembelajaran merupakan alat yang digunakan dalam kegiatan belajar mengajar yang dapat mendorong peserta didik melalui pikiran rangsangan, perasaan, dan kemampuan peserta didik. Media disesuaikan dengan tujuan pembelajaran mampu meningkatkan semangat dan motivasi belajar peserta didik dalam mengikuti pembelajaran sehingga memperoleh hasil belajar yang diinginkan. Oleh karena itu, keberadaan media pembelajaran sangat dibutuhkan dalam proses belajar mengajar dengan tujuan meningkatkan kepahaman dan hasil belajar peserta didik (Hariyanti \& Sakti, 2018).

Berdasarkan pendapat tersebut dapat disimpulkan bahwa keberadaan media pembelajaran sebagai alat fisik digunakan mempermudah pembelajaran yang dapat dipahami dan menarik untuk dipelajari oleh peserta didik. Media yang digunakan bertujuan untuk mendorong semangat dan motivasi belajar peserta didik agar mendapatkan hasil yang diinginkan. Oleh karena itu akan lebih baik disetiap pembelajaran menggunakan media pembelajaran yang menarik dan mudah dipahami oleh peserta didik.

Spinning wheel berasal dari kata spin yang berarti putar dan wheel yang berarti roda, jadi spinning wheel artinya roda berputar. Permainan spinning wheel dimodifikasi untuk media pembelajaran agar pembelajaran yang akan diberikan menjadi menarik dan mudah dipahami. Roda berputar biasanya diisi dengan angka-angka tetapi dalam media pembelajaran diisi dengan gambar-gambar yang sesuai dengan materi pembelajaran yang akan disampaikan. Dalam roda putar terdiri dari jarum penunjuk arah dan berbagai macam gambar yang diletakan pada roda dan digunakan dalam bentuk permainan (Ulya, 2019).

Spinning wheel adalah permainan yang berbentuk lingkaran terdapat berbagai macam gambar di dalamnya yang dimainkan secara berputar sesuai porosnya dan berhenti disalah satu gambar dalam lingkaran. Permainan ini dibuat dengan tujuan agar peserta didik mudah memahami pembelajaran dan membuat pembelajaran menjadi lebih menarik (Hamzah dkk., 2019). Berdasarkan pendapat tersebut disimpulkan bahwa spinning wheel dapat mendukung serta membantu proses peningkatan hasil belajar.

Pembelajaran bahasa Indonesia merupakan salah satu mata pelajaran terpenting di dunia pendidikan. Pelajaran bahasa Indonesia memiliki banyak tujuan yang relevan dengan siswa. Adapun tujuan dari pembelajaran bahasa Indonesia, yaitu (1) peserta didik menghargai dan bangga atas bahasa Indonesia sebagai bahasa persatuan dan bahasa negara, (2) peserta didik memahami bahasa Indonesia baik dari segi bentuk, makna, dan fungsi, (3) peserta didik memiliki kemampuan menggunakan bahasa Indonesia untuk meningkatkan kemampuan diri, kematangan emosional, dan kematangan sosial, (4) peserta didik dapat disiplin dalam berpikir dan berbahasa dalam hal ini berbicara dan menulis, dan (5) peserta didik dapat menghargai dan bangga atas karya sastra Indonesia sebagai budaya dan intektual Indonesia (Hidayah, 2015).

Berdasarkan uraian tersebut dapat disimpulkan bahwa lingkup mata pelajaran bahasa Indonesia di jenjang sekolah dasar 
meliputi kebahasaan, kemampuan memahami, mengapresiasi sastra, dan kemampuan menggunakan bahasa Indonesia yang meliputi empat aspek keterampilan berbahasa itu sendiri. Pembelajaran bahasa Indonesia di jenjang pendidikan dasar atau sekolah dasar dapat diartikan sebagai upaya pendidik untuk mengubah perilaku peserta didik dalam memahami pembelajaran bahasa Indonesia.

Pembelajaran tematik pada dasarnya merupakan model pembelajaran terpadu yang terintegrasi dengan menggunakan tema sehingga dapat memberikan pengalaman belajar yang bermakna kepada peserta didik. Pembelajaran tematik menggunakan tematema yang dekat dengan kehidupan peserta didik, sehingga pembelajaran menjadi lebih bermakna dan mudah untuk dipahami karena peserta didik dapat mencari sendiri dan menemukan apa yang akan mereka pelajari sebagai contoh. Pembelajaran tematik menjadi pembelajaran yang utuh dan menyeluruh digunakan untuk mengembangkan aspek pengetahuan, sikap, dan keterampilan peserta didik. Oleh karena itu pembelajaran tematik diberikan kepada peserta didik dengan tujuan membuat siswa lebih aktif serta mendapatkan pembelajaran yang lebih bermakna baik dari aspek pengetahuan, sikap, dan keterampilan (Trianto, 2011).

Berdasarkan pendapat tersebut dapat ditarik kesimpulan bahwa pembelajaran tematik merupakan strategi pembelajaran yang telah diterapkan untuk siswa sekolah dasar dengan memberikan pembelajaran yang terintegrasi. Pembelajaran tematik dirancang dengan tema-tema yang sangat dekat dengan kehidupan peserta didik, tema itu diambil dari berbagai macam mata pelajaran. Pembelajaran tematik menawarkan kesempatan yang sangat banyak pada peserta didik untuk memunculkan dinamika dalam pendidikan sesuai dengan tahapan perkembangan, karakteristik cara belajar, konsep belajar, dan pembelajaran yang bermakna, maka pembelajaran tematik sangat baik diterapkan dalam peserta didik tingkat dasar.

\section{Metode Penelitian}

Penelitian tindakan kelas (PTK) merupakan suatu pencermatan terhadap kegiatan belajar mengajar berupa sebuah tindakan yang diberikan oleh guru dan diberikan untuk peserta didik dengan tujuan memecahkan masalah, meningkat mutu pembelajaran, serta mendapatkan hasil belajar yang diinginkan. Walaupun tindakan dilakukan di dalam kelas pada saat proses pembelajaran berlangsung namun tidak akan mengganggu proses pembelajaran karena dilakukan sesuai jadwal yang dibuat oleh guru (Arikunto, 2018).

Penelitian ini dilaksanakan di SDN 007 Samarinda Ulu yang beralamat di Jalan Piano, Kecamatan Samarinda Ulu, Kota Samarinda. Adapun waktu pelaksanaan dilaksanakan selama 2 bulan. Subjek yang akan diteliti dalam penelitian tindakan kelas (PTK) merupakan hasil belajar peserta didik dengan menggunakan media pembelajaran spinning wheel. Adapun tahapan-tahapan penelitian tindak kelas (PTK) terdiri dari 4 tahapan, meliputi perencanaan (planning), pelaksanaan (action), observasi (observation), dan refleksi (reflection). 


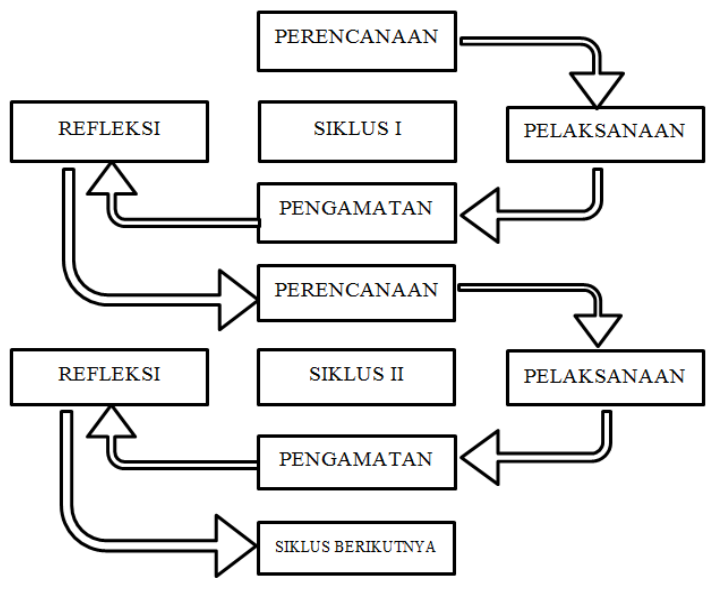

Gambar 1 Siklus Penelitian (Arikunto, 2018)

\section{Siklus 1}

\section{a. Tahapan Perencanaan (Planning)}

Tahap perencanaan yaitu menyusun rencana untuk melakukan kegiatan pembelajaran. Rencana yang dibuat berdasarkan hasil diskusi dengan wali kelas.

1) Menentukan jadwal kegiatan pembelajaran, membuat pemetaan kompetensi dasar, membuat silabus, membuat rencana pelaksanaan pembelajaran (RPP), membuat lembar kerja peserta didik, dan membuat lembar observasi.

2) Menetukan standar kompetensi (SK) dan kompetensi dasar (KD).

3) Membuat skenario menggunakan media spinning wheel.

4) Mempersiapkan sumber bahan dan alat yang diperlukan sebagai media pembelajaran.

\section{b. Tahapan Pelaksanaan (Action)}

Pelaksanaan berupa kegiatan pembelajaran yang telah disusun dalam perencanaan. Kegiatan pelaksanaan terdiri dari kegiatan awal, kegiatan inti, dan kegiatan akhir.
1) Kegiatan awal

a) Mengawali pembelajaran dengan mengucapkan salam dan mengajak peserta didik untuk berdoa.

b) Guru menanyakan kehadiran peserta didik.

c) Guru mengaitkan materi pembelajaran sebelumnya dengan materi selajutnya.

2) Kegiatan inti

a) Guru menyampaikan materi dengan menggunakan media spinning wheel.

b) Guru membagi siswa menjadi beberapa kelompok.

c) Siswa diberi kartu angka untuk menentukan kelompok yang bermain spinning wheel terlebih dahulu.

d) Siswa memutar media spinning wheel dan mendapatkan gambar sesuai dengan gambar yang ditunjukan oleh jarum pada media.

e) Siswa diberikan kartu pertanyaan dan harus didiskusikan jawabannya bersama dengan kelompok.

3) Kegiatan akhir

a) Guru memberikan soal evaluasi.

b) Guru mengajak peserta didik untuk berdoa sebelum pulang.

\section{c. Tahapan Observasi (Observation)}

Tahapan observasi merupakan pengamatan yang dilakukan pada peserta didik, pada saat proses pembelajaran berlangsung dengan menggunakan media. Pengamatan dilakukan menggunakan lembar observasi yang telah disiapkan peneliti.

\section{d. Tahapan Refleksi (Reflection)}

Tahapan refleksi merupakan kegiatan evaluasi dan menganalisis hasil belajar yang 
diperoleh peserta didik. Refleksi dilakukan oleh peneliti sebagai hasil pengamatan pengamatan yang telah dilakukan dengan mencatatn kekurangan yang harus diperbaiki. Menganalisis hasil tindakan sebagai gambaran untuk perencanaan untuk siklus selanjutnya.

Siklus 2

Peneliti menyusun rancangan siklus 2 untuk memperbaiki kekurangan yang terdapat pada siklus 1. Tahapan pelaksanaan pada siklus 2 sama dengan tahapan pelaksanaan siklus 1. Akan tetapi lebih dimaksimalakan untuk memperoleh hasil pembelajaran yang lebih baik.

\section{Teknik Pengumpulan Data}

Teknik pengumpulan data yang akan digunakan oleh peneliti dengan melakukan observasi, dokumentasi, dan tes dalam pengumpulan data peneliti dibantu oleh guru kelas V Adapun penjelasnya, sebagai berikut:

Observasi merupakan pengambilan data dengan melakukan pengamatan aktivitas peserta didik terhadap tindakan dan perilaku responden serta peneliti mencatat hasil penelitian untuk dianalisis. Adapun data observasi yang dilakukan untuk mengumpulkan yaitu (1) Data aktivitas peserta didik pada saat pembelajaran dengan menggunakan media pembelajaran spinning wheel (2) Data aktivitas guru pada saat melakukan pembelajaran yang diamati oleh guru wali kelas.

Dokumentasi merupakan teknik pengumpulan data yang diperoleh oleh peneliti. Dokumentasi sangat dibutuhkan berkaitan dengan data yang relevan dalam penelitian tindak kelas. Beberapa data yang diperoleh dari dokumentasi, antara lain: data nilai peserta didik prasiklus, silabus, rpp, presensi, foto, dan video selama tindakan berlangsung, data hasil tes peserta didik setelah siklus berlangsung, lembar kerja peserta didik, dan meteri yang digunakan pada saat pembelajaran.

Tes digunakan untuk mengambil data berupa pernyataan atau pertanyaan bertujuan mengukur pengetahuan, keterampilan dan sikap peserta didik setelah proses pembelajaran berlangsung. Tes digunakan untuk pengumpulan data mengenai hasil belajar peserta didik di kelas V D SDN 007 Samarinda Ulu setelah diberikan tindakan dengan menggunakan media spinning wheel.

\section{Instrumen Penelitian}

Lembar observasi atau lembar pengamatan digunakan untuk mengumpulkan data dan mencatat kejadian selama proses pembelajaran berlangung. Lembar observasi yang digunakan adalah lembar observasi untuk peserta didik dan untuk guru (peneliti). Lembar observasi untuk peserta didik digunakan untuk melihat sejauh mana keaktifan peserta didik dalam proses pembelajaran dengan melihat ranah apektif dan ranah psikomotorik meningkat atau menurun ketika menggunakan media spinning wheel. Sedangkan, lembar observasi untuk guru digunakan untuk melihat kegiatan yang dilakukan guru selama proses pembelajaran dengan rencana pelaksanaan pembelajaran selama tindakan dilakukan.

\section{Teknik Analisis Data}

Analisis data yang digunakan dalam penelitian ini adalah analisis data kualitatif yang dapat dianalisis secara deskriptif. Penelitian ini menggunakan rata-rata dan 
presentase yang akan diuraikan sebagai berikut:

Rata-rata digunakan untuk mengetahui hasil belajar dan peningkatan hasil belajar peserta didik dalam satu kelas. Penelitian ini menggunakan rata-rata dengan rumus:

$\bar{x}=\frac{\Sigma x}{n}$

Keterangan:

$x=$ rata-rata

$\Sigma \mathrm{x}=$ jumlah seluruh nilai peserta didik

$\mathrm{n}=$ jumlah peserta didik

Indikator keberhasilan dalam penelitian yaitu presentase hasil belajar peserta didik mengalami peningkatan dari siklus I kesiklus berikutnya dengan kriteria ketuntasan minimal (KKM) sebesar 70 dari nilai sekolah. Aktivitas belajar peserta didik dikatakan meningkat apabila dalam proses pembelajaran yang dilakukan menggunakan media spinning wheel terlihat adanya peningkatan aktivitas belajar peserta didik dari berkategori aktif atau baik.

\section{Hasil dan Pembahasan}

Penelitian ini dilakukan sebanyak dua siklus. Masing-masing siklus terdiri dari tiga kali pertemuan. Masing-masing pertemuan berlangsung selama $2 \times 35$ menit. Setiap memasuki pertemuan ketiga dilakukan tes untuk mengetahui peningkatan hasil belajar, peneliti terlebih dahulu melakukan observasi di kelas tersebut. Setelah dilakukan observasi, diperoleh data hasil belajar siswa. Diketahui bahwa hasil belajar siswa pada kondisi awal masih tergolong rendah dengan nilai rata-rata 65,5. Analisis ini dapat dilihat pada tabel 1 dan gafik 1 .
Tabel 1 Analisis Kriteria Hasil Belajar Siswa pada Kondisi Awal

\begin{tabular}{|c|c|c|c|}
\hline $\begin{array}{c}\text { Nilai } \\
\text { Siswa }\end{array}$ & $\begin{array}{c}\text { Nilai } \\
\text { Huruf }\end{array}$ & $\begin{array}{c}\text { Fruekuensi } \\
\text { (Jumlah } \\
\text { siswa) }\end{array}$ & Kriteria \\
\hline $80-100$ & A & 1 & $\begin{array}{c}\text { Baik } \\
\text { Sekali }\end{array}$ \\
\hline $66-79$ & B & 18 & Baik \\
\hline $56-65$ & C & 6 & Cukup \\
\hline $40-55$ & D & 4 & Kurang \\
\hline $30-39$ & E & 1 & $\begin{array}{c}\text { Kurang } \\
\text { Sekali }\end{array}$ \\
\hline
\end{tabular}

Grafik 1 Hasil Belajar Siswa pada Kondisi Awal

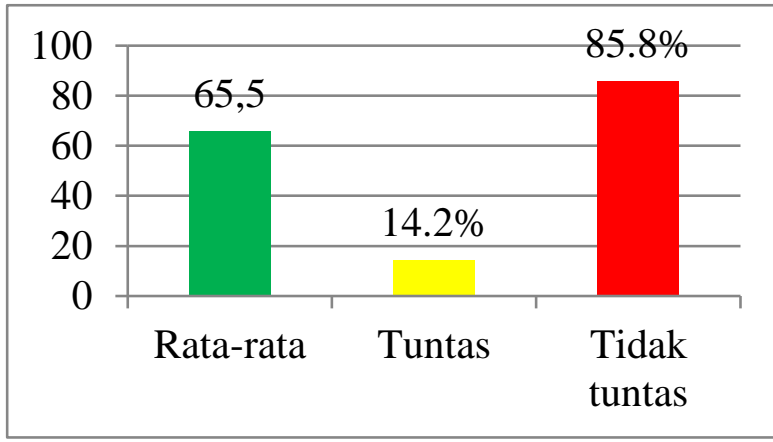

\section{Siklus I}

Siklus I terdiri dari 3 kali pertemuan, yaitu pertemuan pertama, kedua, dan ketiga. Waktu pembelajaran yang digunakan disetiap pertemuan adalah 70 menit, dengan keseluruhan waktu pembelajaran yang digunakan pada siklus I adalah 210 menit. Dalam penelitian ini, siklus I dilaksanakan dengan empat tahapan yaitu sebagai berikut.

\section{1) Perencanaan}

Berdasarkan hasil nilai siswa pada semester I yang dilaksanakan sebelumnya, nilai bahasa Indonesia kelas $\mathrm{V}$ dari 30 siswa, yang mencapai kriteria ketuntasan minimal (KKM) yaitu 10 orang siswa (14.2\%). Sedangkan 20 orang (85.8\%) belum mencapai kriteria ketuntasan minimal (KKM).

\section{2) Pelaksanaan}

Pada tahap pelaksanaan ini dilakukan 3 kali pertemuan di mana 
pertemuan satu dan pertemuan kedua menyampaikan materi sedangkan pertemuan ketiga melakukan tes hasil belajar siswa. Selama pembelajaran ada beberapa masalah yang dihadapi pada siklus I siswa masih banyak bercerita di dalam kelas tidak memperhatikan penjelasan guru dan berjalan-jalan ke tempat duduk temannya serta izin berkali-kali ke toilet.

Pertemuan kedua siklus I guru menggunakan spinning wheel untuk menarik minat belajar dan motivasi belajar siswa dalam mengikuti pembelajaran. Namun hal yang ditemui masih sama pada pertemuan pertama, siswa pada pertemuan kedua masih ribut, tidak mau mendengar penjelasan guru di depan kelas dan sibuk mengobrol dengan temannya serta mengganggu temannya, hanya ada beberapa siswa yang bersemangat dan termotivasi. Pertemuan ketiga siklus satu ini guru mengulang kembali materi yang disampaikan pada pertemuan satu dan dua sebelum melakukan tes.

Berdasarkan tabel dapat diketahui hasil belajar siswa pada siklus I sudah tergolong cukup dengan nilai rata-rata 69,5. Adapun peningkatan hasil belajar dari kondisi awal ke siklus I sebesar 30,5\% analisis hasil siswa dapat dilihat pada tabel 2 dan grafik 2.

Tabel 2 Analisis Kriteria Hasil Belajar Siswa pada Siklus I

\begin{tabular}{|c|c|c|c|}
\hline $\begin{array}{c}\text { Nilai } \\
\text { Siswa }\end{array}$ & $\begin{array}{c}\text { Nilai } \\
\text { Huruf }\end{array}$ & $\begin{array}{c}\text { Fruekuensi } \\
\text { (Jumlah } \\
\text { siswa) }\end{array}$ & Kriteria \\
\hline $80-100$ & A & 8 & Baik Sekali \\
\hline $66-79$ & B & 11 & Baik \\
\hline $56-65$ & C & 7 & Cukup \\
\hline $40-55$ & D & 4 & Kurang \\
\hline $30-39$ & E & - & $\begin{array}{c}\text { Kurang } \\
\text { Sekali }\end{array}$ \\
\hline
\end{tabular}

\section{Grafik 2 Hasil Belajar Siswa pada Siklus I}

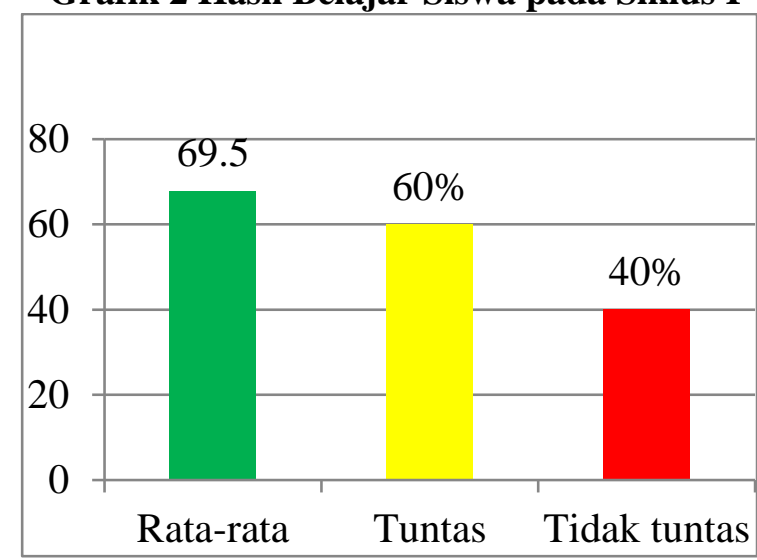

\section{3) Wawancara}

Dari hasil wawancara yang dilakukan oleh peneliti, selama proses pembelajaran guru kelas belum pernah menggunakan spinning wheel dalam kegiatan pembelajaran sehingga siswa merasa bosan, tidak berminat, dan tidak termotivasi dalam kegiatan pembelajaran tersebut.

\section{4) Observasi}

Hasil dari observasi pada siklus I pertemuan pertama, pertemuan kedua, dan pertemuan ketiga telah dilaksanakan. Selama tiga kali pertemuan banyak masalah yang dihadapi. Banyak siswa yang tidak mau bergabung kelompok dengan siswa lainnya dan banyak siswa yang ribut, sehingga menciptakan suasana kelas yang kurang kondusif. Akibatnya siswa tidak dapat berkonsentrasi dengan baik.

\section{5) Refleksi}

Setelah melaksanakan kegiatan pembelajaran pada siklus I, kemudian peneliti melakukan refleksi terhadap proses kegiatan pembelajaran. Refleksi digunakan sebagai bahan pertimbangan untuk melanjutkan kegiatan pembelajaran pada siklus II. Berdasarkan data-data yang 
diperoleh peneliti dapat menyimpulkan bahwa dari hasil tes evaluasi diakhir siklus menunjukan bahwa hasil belajar pada siklus I yaitu dengan rata-rata 69,5. Dari hasil tersebut menunjukan belum mencapai keriteria ketuntasan minimum (KKM) yaitu $\geq 70$ dari keseluruhan yang belum mencapai keriteria ketuntasan minimum (KKM) $\geq$ $80 \%$ maka dari itu dilanjutkan pada siklus II.

\section{Siklus II}

Siklus II terdiri dari 3 kali pertemuan, yaitu pertemuan pertama, kedua, dan ketiga. Waktu pembelajaran yang digunakan disetiap pertemuan adalah 70 menit. Dengan keseluruhan waktu pembelajaran yang digunakan pada siklus II adalah 210 menit. Dalam penelitian ini, siklus II dilaksanakan dengan empat tahapan yaitu sebagai berikut.

\section{1) Perencanaan}

Berdasarkan

hasil refleksi pelaksanaan pada siklus I telah diketahui bahwa belum adanya peningkatan hasil belajar siswa dengan menggunakan spinning wheel pada pembelajaran bahasa Indonesia. Oleh, karena itu yang perlu dilakukan perencanaan pada siklus yang ke II. Peneliti akan memberikan arahan kembali pada siswa serta memperbaiki pengolahan kelas.

\section{2) Pelaksanaan}

Pada tahap pelaksanaan ini dilakukan 3 kali pertemuan di mana pertemuan pertama dan kedua menyampaikan materi sedangkan pada pertemuan ketiga melakukan tes hasil belajar siswa. Tindakan pada siklus II dilaksanakan tiga kali pertemuan, dua kali pertemuan untuk mengajarkan materi dan pertemuan ketiga tes. Selama pelaksanaan pembelajaran ada beberapa masalah yang dihadapi peneliti masih ada beberapa siswa yang sibuk berbicara dengan temannya pada saat guru menjelaskan tapi pada siklus ini siswa terlihat lebih aktif dan siap mengikuti pembelajaran dari pada siklus I.

Pada saat guru meminta untuk menyiapkan ruang kelas untuk memulai kegiatan pembelajaran masih ada beberapa siswa yang masih sibuk berbicara pada jam pembelajaran. Akan tetapi pada saat pembelajaran terlihat siswa berminat dan termotivasi mengikuti kegiatan pembelajaran dan terlihat lebih siap mengikuti pembelajaran. Ini terlihat siswa lebih aktif dan siap dalam belajar.

Pada pertemuan kedua siklus kedua dilaksanakan guru melanjutkan materi dari pertemuan pertama dengan menggunakan spinning wheel, siswa terlihat antusias dan bersemangat dalam belajar dan siswa terlihat lebih siap mengikuti pembelajaran. Pertemuan ketiga ini guru mengulang kembali materi yang disampaikan pada pertemuan satu dan dua sebelum melakukan tes. Berdasarkan tabel dapat diketahui hasil belajar siswa pada siklus II sudah tergolong baik dengan nilai rata-rata 81,3. Adapun peningkatan hasil belajar siswa dari siklus I ke siklus II sebesar 18,7\%. Analisis hasil belajar siswa pada siklus II dapat dilihat pada tabel 3 dan grafik 3 .

Tabel 3 Analisis Kriteria Hasil Belajar Siswa pada Siklus II

\begin{tabular}{|c|c|c|c|}
\hline $\begin{array}{c}\text { Nilai } \\
\text { Siswa }\end{array}$ & $\begin{array}{c}\text { Nilai } \\
\text { Huruf }\end{array}$ & $\begin{array}{c}\text { Fruekuensi } \\
\text { (Jumlah } \\
\text { siswa) }\end{array}$ & Kriteria \\
\hline $80-100$ & A & 20 & $\begin{array}{c}\text { Baik } \\
\text { Sekali }\end{array}$ \\
\hline $66-79$ & B & 6 & Baik \\
\hline $56-65$ & C & 4 & Cukup \\
\hline $40-55$ & D & - & Kurang \\
\hline
\end{tabular}




\section{0-39}

$\mathrm{E}$

E

(n)

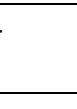

Kurang

Sekali

Grafik 3 Hasil Belajar Siswa Siklus II

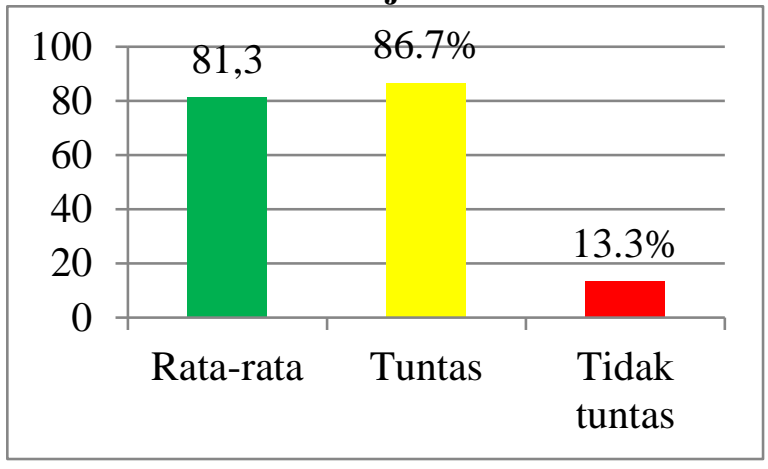

\section{3) Wawancara}

Dari hasil wawancara yang dilakukan oleh peneliti, selama belajar guru kelas belum menggunakan spinning wheel dalam kegiatan pembelajaran sehingga siswa merasa bosan, tidak berminat, dan tidak termotivasi dalam kegiatan pembelajaran tersebut.

\section{4) Observasi}

Hasil dari observasi pada siklus II pertemuan pertama, pertemuan kedua, dan pertemuan ketiga selama pertemuan disiklus ini siswa terlihat lebih semangat dan siap dalam mengikuti kegiatan pembelajaran yang sedang berlangsung. Kemudian peneliti melanjutkan dengan menjelaskan materi.

\section{5) Refleksi}

Setelah melaksanakan kegiatan pembelajaran pada siklus II, kemudian peneliti melakukan refleksi terhadap proses kegiatan pembelajaran. Refleksi ini digunakan sebagai bahan pertimbangan untuk melanjutkan kegiatan pembelajaran. Berdasarkan data-data yang diperoleh, peneliti dapat menyimpulkan bahwa dari hasil tes evaluasi diakhir siklus ini menunjukan bahwa hasil belajar bahasa Indonesia pada siklus II mengalami peningkatan dan hasil ketuntasan belajar siswa kelas V SDN 007 Samarinda Ulu telah mencapai $81,33 \%$. Dari hasil tersebut peneliti menyatakan berhasil dan penelitian pun dihentikan.

\section{Grafik 4 Peningkatan Hasil Belajar dari Prasiklus, Siklus I, dan Siklus II}

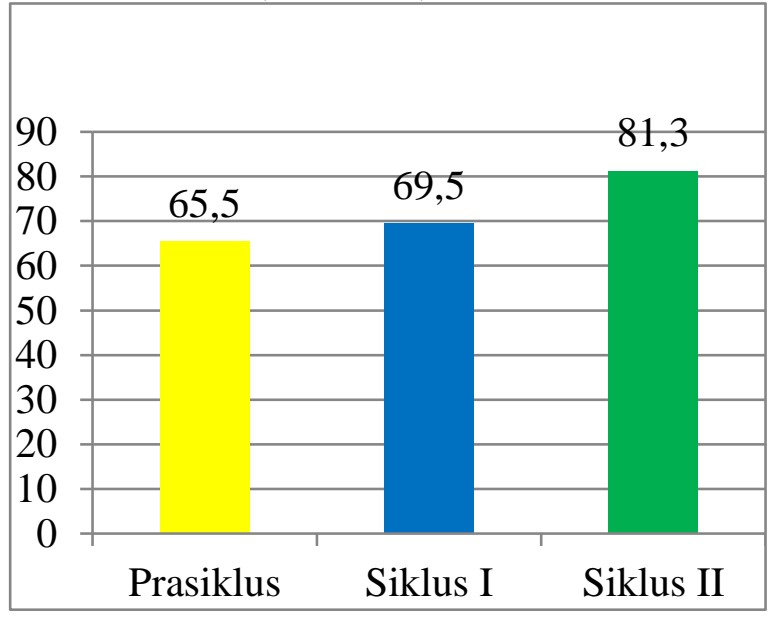

\section{Pembahasan}

Tindakan siklus I dilaksanakan sebanyak tiga kali pertemuan, dua kali pertemuan untuk mengajarkan materi dan pertemuan ketiga untuk melaksanakan tes. Selama pembelajaran ada beberapa masalah yang dihadapi pada siklus I siswa masih banyak bercerita di dalam kelas, tidak memperhatikan penjelasan guru, berjalanjalan ke tempat duduk temannya, dan izin berkali-kali ke toilet. Pada saat guru menjelaskan kontrak spinning wheel dan poin-poin pembelajaran kelas menjadi ribut sehingga situasi kelas menjadi sangat ramai dan waktu yang digunakan menjadi sangat lama ada sekitar 4 orang siswa yang berteriak di dalam kelas. Sementara itu, sebanyak 7 orang siswa lainnya yang sibuk bercerita dengan temannya dan tidak memperhatikan penjelasan guru. Lalu 
terdapat beberapa siswa yang masih kebingungan dalam pembelajaran dengan menggunakan spinning wheel sehingga membutuhkan waktu yang cukup lama dalam menjelaskan kontrak spinning wheel yang disampaikan oleh guru.

Sedangkan pertemuan kedua siklus satu, guru kembali menggunkan spinning wheel untuk menarik minat belajar dan motivasi belajar siswa dalam mengikuti pembelajaran dengan membagi beberapa kelompok yang ditentukan oleh guru untuk melakukan kegiatan. Namun hal yang ditemui masih sama pada pertemuan pertama, siswa pada pertemuan kedua masih ribut, tidak mau mendengar penjelasan guru di depan kelas dan sibuk mengobrol dengan temannya serta mengganggu temannya, hanya ada beberapa siswa yang bersemangat dan termotivasi dengan menggunakan spinning wheel sebagai motivasi dan menarik minat belajar siswa.

Pertemuan ketiga siklus satu ini guru mengulang kembali materi yang disampaikan pada siklus satu dan dua sebelum melakukan tes. Adapun hasil belajar dapat terlihat dalam grafik 5 .

Grafik 5 Hasil Belajar Prasiklus dan Siklus I

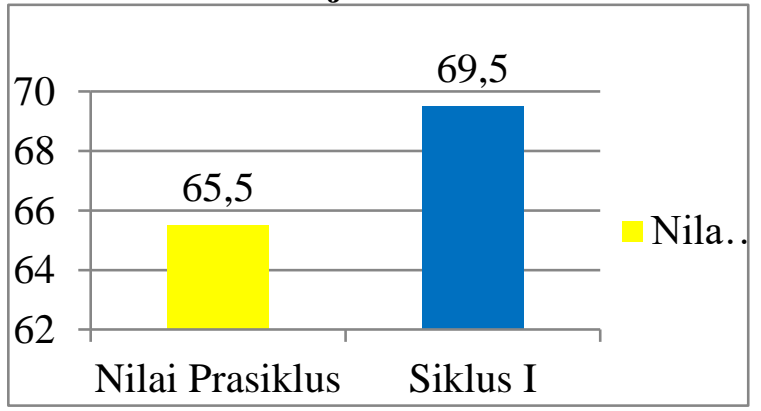

Pada grafik 5 tersebut menunjukan bahwa perbandingan hasil belajar nilai prasiklus dan siklus I mengalami peningkatan hasil belajar dari 65,5 menjadi 69,5 pada siklus I. Karena dari data nilai semester I (prasiklus) siswa kelas V yang peneliti peroleh dari wali kelas V menunjukan bahwa proses pembelajaran terganggu oleh lingkungan sekolah yang berdekatan dengan rumah penduduk serta adanya anak-anak yang bermain di dalam lingkungan sekolah sehingga siswa tidak berkonsentrasi. Hal ini yang membuat siswa tidak tertarik belajar dan termotivasi saat proses pembelajaran. Sedangkan pada siklus I peneliti menggunakan spinning wheel. Ini dapat membuat siswa tertarik belajar dan termotivasi terlihat dari data siklus I membuktikan bahwa menggunakan spinning wheel cukup efektif menarik minat belajar dan motivasi siswa khususnya pembelajaran bahasa Indonesia. Untuk mengetahui ketuntasan belajar siswa pada nilai prasiklus dan siklus I dapat dilihat pada grafik 6 .

\section{Grafik 6 Perbandingan Presentase Prasiklus dan Siklus I}

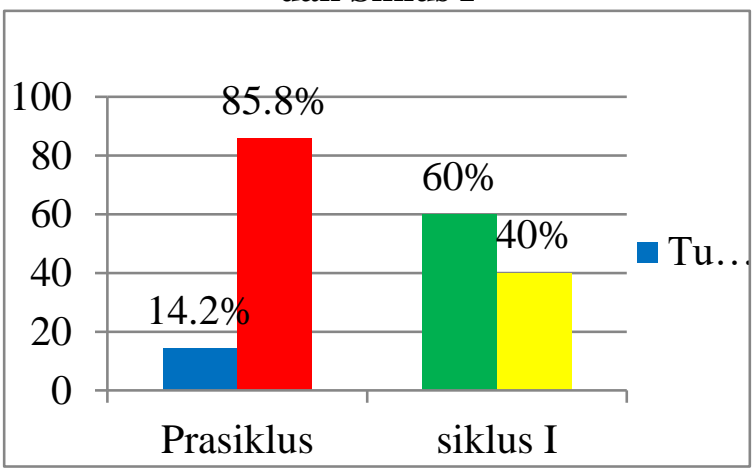

Dari grafik 6 tersebut dapat dilihat ketuntasan pada prasiklus dan siklus I mengalami peningkatan ketuntasan. Pada prasiklus hanya 10 orang siswa yang tuntas dan 20 orang siswa tidak tuntas karena tidak mencapai KKM dalam pembelajaran muatan bahasa Indonesia. Sedang pada siklus I siswa yang tuntas adalah 18 orang siswa dan 12 orang siswa tidak tuntas. Terjadinya peningkatan karena proses pembelajaran yang terganggu oleh 
lingkungan sekolah yang berdekatan dengan rumah penduduk serta adanya anak-anak yang di dalam lingkungan sekolah bermain sehingga siswa tidak berkonsentrasi dalam proses pembelajaran. Sedangkan pada siklus I menggunakan spinning wheel yang dapat menarik perhatian siswa serta tertarik belajar dan termotivasi sehingga siswa mudah memahami materi yang disampaikan oleh peneliti dengan materi yang diajarkan.

Tindakan siklus II dilaksanakan sebanyak tiga kali pertemuan, dua kali pertemuan untuk mengajarkan materi dan pertemuan ketiga untuk melaksanakan tes. Selama pelaksanaan pembelajaran berlangsung terdapat beberapa masalah yang dihadapi peneliti. Adapun masalah yang dihadapi yaitu masih ada beberapa siswa yang sibuk berbicara dengan temannya pada saat guru menjelaskan. Akan tetapi pada siklus ini siswa terlihat lebih aktif dan siap mengikuti pembelajaran. Pada saat guru meminta untuk menyiapkan ruang kelas untuk memulai kegiatan pembelajaran masih ada beberapa siswa yang masih sibuk berbicara pada jam pembelajaran. Saat pembelajaran terlihat siswa berminat dan termotivasi mengikuti kegiatan pembelajaran dan terlihat lebih siap mengikuti pembelajaran. Ini terlihat siswa lebih aktif dan siap dalam belajar.

Pada pertemuan kedua siklus kedua dilaksanakan guru melanjutkan materi dari pertemuan pertama dengan menggunakan spinning wheel. Siswa terlihat antusias dan bersemangat dalam belajar. Siswa terlihat lebih siap mengikuti pembelajaran, siswa tidak mengalami kesulitan mengikuti spinning wheel. Pertemuan ketiga siklus satu ini guru mengulang kembali materi yang disampaikan sebelunya. Hasil belajar siswa pada siklus II telah mencapai $81,3 \%$ dapat dikatakan bahwa pada siklus II telah mencapai ketuntasan yang diharapkan oleh peneliti. Bahwa siklus II ada empat siswa tidak mencapai ketuntasan dikarenakan satu orang siswa tidak mengikuti evaluasi penelitian serta dibutuhkan tindakan khusus terhadap tiga orang siswa dalam kegiatan pembelajaran. Namun tidak ditemukan lagi masalah dalam proses belajar mengajar seperti siklus sebelumnya, seluruh siswa kelas $\mathrm{V}$ telah mencapai kriteria ketuntasan minimum (KKM) yang ditentukan yaitu 70 untuk mata pelajaran muatan bahasa Indonesia. Dengan memperoleh nilai ratarata 81,3 . Untuk mengetahui perbandingan hasil belajar prasiklus, siklus I dan siklus II dapat dilihat pada grafik 7 .

\section{Grafik 7 Hasil Belajar Prasiklus, Siklus I,} dan Siklus II

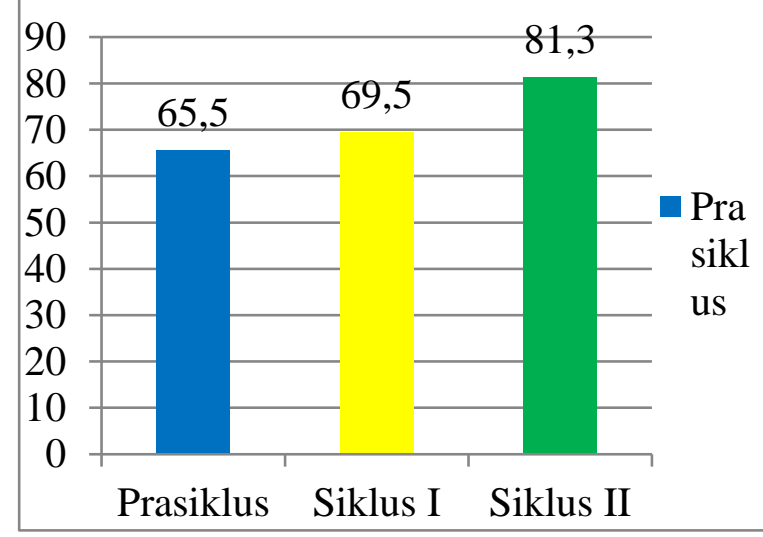

Dari grafik hasil belajar di atas menunjukan bahwa terjadinya peningkatan dari prasiklus sampai siklus II. Hal ini ditunjukan bahwa dari hasil nilai prasiklus sebesar 65,5 menjadi 69,5 pada siklus I dan meningkat lagi pada siklus II yaitu sebesar 81,3 . Hal ini terjadi karena siswa sudah memahami, tertarik untuk belajar, dan termotivasi dalam belajar dengan 
menggunakan spinning wheel. Untuk mengetahui ketuntasan siswa dari prasiklus, siklus I dan siklus II dapat dilihat pada grafik 8.

\section{Grafik 8 Perbandingan Presentase Belajar} Prasiklus, Siklus I, dan Siklus II

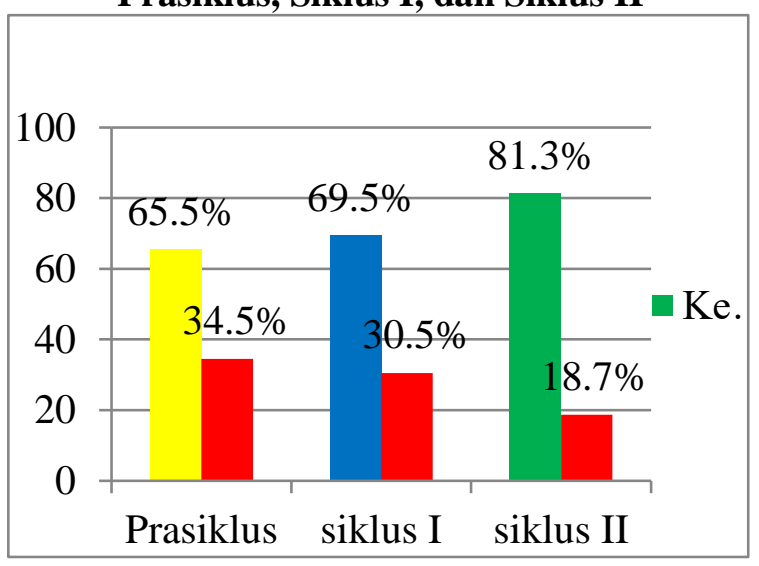

Grafik tersebut menunjukan bahwa ketuntasan siswa dari prasiklus, siklus I dan siklus II, mengalami peningkatan yang cukup baik karena pada siklus II ini siswa mencapai 81,3\%. Siswa sangat tertarik untuk belajar dan termotivasi dengan menggunakan spinning wheel. Akhirnya sebagian besar siswa mencapai ketuntasan di atas kriteria ketuntasan minimum (KKM) 70. Hasil penelitian tindakan kelas (PTK) ini telah terlaksana dengan baik dan berhasil dari awal pengambilan data sampai penelitian ini selesai dilaksanakan. Untuk ketuntasan pada prasiklus dengan nilai ratarata 65,5 dengan ketuntasan belajar 14.2\% pada siklus I nilai rata-rata 69,5 dengan ketuntasan belajar $60 \%$ dan siklus II nilai rata-rata 81,3 dengan ketuntasan belajar $86,7 \%$.

Berdasarkan hasil data yang telah diperoleh menunjukan semangat belajar siswa menjadi lebih baik pada mata pelajaran muatan bahasa Indonesia dengan menggunakan spinning wheel. Hasil belajar siswa telah mencapai kriteria ketuntasan maksimal (KKM) yang telah ditetapkan yaitu 70. Dari hasil yang diperoleh pada siklus II dapat dikatakan bahwa hasil belajar siswa dengan pembelajaran muatan bahasa Indonesia telah meningkat.

\section{Simpulan}

Berdasarkan hasil penelitian dan pembahasan dapat disimpulkan bahwa pembelajaran muatan bahasa Indonesia menggunakan spinning wheel dapat meningkatkan hasil belajar siswa kelas V SDN 007 Samarinda Ulu Tahun Pembelajaran 2019/2020. Hal ini dapat dilihat dari ketuntasan belajar pada siklus I dan siklus II dibandingkan dengan hasil observasi sebelum dilakukannya tindakan yaitu nilai semester I siswa kelas V SDN 007 Samarinda Ulu. Ketuntasan belajar tersebut menunjukkan peningkatan dari nilai prasiklus semester I yaitu $33.5 \%$ menjadi $40 \%$ di siklus I, kemudian sampai akhirnya meningkat menjadi $81,3 \%$ di siklus II. Dengan demikian spinning wheel dinyatakan dapat meningkatkan hasil pembelajaran bahasa Indonesia di kelas V SDN 007 Samarinda Ulu.

Adapun saran-saran yang dapat peneliti berikan setelah melakukan penelitian antara lain:

1) Guru

Diharapkan guru dapat menggunakan pembelajaran yang menarik, kreatif, dan aktif secara tepat dalam kegiatan belajar mengajar sehingga dapat menciptakan rasa senang kepada anak dalam pembelajaran muatan bahasa Indonesia sehingga membuat anak lebih semangat, aktif, dan hasil belajar dapat meningkat.

2) Siswa

Diharapkan siswa lebih aktif dan kreatif dalam pembelajaran sehingga 
terbiasa dengan menggunakan spinning wheel serta metode lain. Maupun pembelajaran lainnya.

3) Sekolah

Diharapkan sekolah dapat mendukung kegiatan pembelajaran dengan menekankan penerapan media-media pembelajaran yang lebih efektif dan bervariasi khususnya pada pembelajaran bahasa Indonesia dengan menggunakan spinning wheel.

4) Peneliti lain

Diharapkan bagi peneliti lain yang ingin meneliti dengan topik pembahasan yang sama agar lebih memperhatikan subjek penelitiannya sehingga akan lebih mudah dan efektif dalam menerapkan spinning wheel.

\section{Daftar Pustaka}

Anggraini, P., \& Ningrum, M. a., (2018). Pengembangan Media Roda Putar Untuk Meningkatkan Kemampuan Mengenal Bentuk Geometri Anak Usia 4-5 Tahun. PAUD Teratai, 7(3), 1-6. Surabaya. Universitas Negeri Surabaya.

Arikunto, S. (2018). Prosedur Penelitian Suatu Pendekatan Praktik. Bandung. Rineka Cipta.

Bahtiar, R. S. (2017). Penggunaan Media Visual Untuk Meningkatkan Hasil Belajar Siswa Pada Tema Lingkungan Siswa Kelas II Sekolah Dasar. Pgsd, 01, 1-10. Surabaya. Universitas Negeri Surabaya.

Daryanto. (2014). Evaluasi Pendidikan. Jakarta. Rineka Cipta.

Ernawati. (2019). Peningkatan Menulis Teks Diskusi Menggunakan Model Kooperatif Learning dengan Tipe
Debat Pada Siswa Kelas VIII H SMP Negeri 1 Rejang Lebong. Disastra:Jurnal Pendidikan Bahasa dan Sastra Indonesia, 1(2), 78-89 http://ejournal.iainbengkulu.ac.id/index.php /disastra. Bengkulu. Institut Agama Islam Negeri Bengkulu.

Hamzah, H., Utami, L. S., \& Zulkarnain, Z. (2019). Pengembangan Media Pembelajaran Roda Putar Fisika Untuk Meningkatkan Motivasi Belajar Siswa. ORBITA: Jurnal Kajian, Inovasi Dan Aplikasi Pendidikan Fisika, 5(2), 77.

https://doi.org/10.31764/orbita.v5i2.11

92. Mataram. Universitas

Muhammadiyah Mataram.

Ibda, Hamidulloh. (2020). Peningkatan Menulis Resensi Buku Ilmiah pada Mahasiswa Melalui Program Satu Semester Satu Resensi (Tuter Tensi). Disastra: Jurnal Pendidikan Bahasa dan Sastra Indonesia, 2(1), 1-13 http://ejournal.iainbengkulu.ac.id/index.php /disastra. Bengkulu. Institut Agama Islam Negeri Bengkulu.

Maolani, A. R., \& Cahyana, U. (2007). Metodologi Penelitian Pendidikan. Jakarta. Rajagrafindo Persada.

Matondang, Z., Ely, D., Sriadhi, \& Janner, S. (2019). Evaluasi Hasil Belajar. Medan:Yayasan Kita Menulis.

Ratnawulan, E., \& Rusdiana. (2017). Evaluasi Pembelajaran. Bandung. Pustaka Setia.

Situmorang, Manihar. (2018). Penelitian Tindakan Kelas. Depok: Rajagrafindo Persada.

Subakti, Hani. (2019). 8 Konsepsi Landasan Bahasa Indonesia di Perguruan Tinggi. 
Volume 2, Nomor 2, Juli 2020 ISSN 2655-3031 (P), 2655-7851 (O)

Parepare: Kaaffah Learning Center.

Sugiyono. (2018). Metode Penelitian

Pendidikan Pendekatan Kualitatif,

Kuantitatif, dan $R \& D$.

Bandung:Alfabeta.
Ulya, A. I. (2019). Pengembangan Media Pembelajaran Game Spinning Wheel Berbasis Model 4d Pada Materi Pelajaran Alat Panca Indera. Semarang. Fakultas Ilmu Pendidikan. Universitas Negeri Semarang.

Syarifudin, Supiono, \& Burhanuddin.

(2019). Guru, Mari Kita Menulis

Penelitian Tindakan Kelas.

Yogyakarta: Deepublish. 